\title{
Penggunaan Boraks Sebagai Bahan Pengawet Substrat Serat Aren untuk Hidroponik Tomat
}

\section{The Use of Borax as a Preservative of Palm Fiber Substrate for Tomato Hydroponics}

\author{
Rena Satya Tungga Dewi*, Dwi Harjoko, Retna Bandriyati Arniputri \\ Department of Agrotechnology, Faculty of Agriculture, Universitas Sebelas Maret, Surakarta, Indonesia \\ ${ }^{*}$ Corresponding author: rennasatya@gmail.com
}

Received: November 19, 2019; Accepted: January 30, 2020; Published: April 1, 2020

\begin{abstract}
Palm fiber from palm flour industries waste often causes problems when used as a planting medium such as easy to decompose. The plants used are tomatoes, because of their low production due to the use of fertilizers and planting media that are not yet right. One of the cultivation techniques that is expected to improve yields and quality of tomatoes is hydroponics. The research aimed to knowing the effect of borax on palm fiber decomposition after it is used for tomato cultivation. The research was carried out at Greenhouse B Faculty of Agriculture, Universitas Sebelas Maret, Surakarta from January-July 2019. The method used was Completely Randomized Factorial Design with 2 factors and 3 replications. The first factor was the soaking time of the palm fiber substrate in the borax solution $10 \%$ of concentration, which is $0,1,2,3$ and 4 days. The second factor was the variety of tomato varieties, namely Servo and Ken Dedes. The results showed that soaking treatment not significantly affected to almost all observed variables and tomato varieties not significantly affected to the growth and yield.
\end{abstract}

Key words: growing media, decomposition, soaking treatment

Cite this as: Dewi, R. S. T., Harjoko, D., \& Arniputri, R. B. (2020). Penggunaan Boraks Sebagai Bahan Pengawet Substrat Serat Aren untuk Hidroponik Tomat. Agrosains : Jurnal Penelitian Agronomi 22(1): 25-31. DOI: http://dx.doi.org/10.20961/agsjpa.v22i1.35677

\section{PENDAHULUAN}

Di Indonesia produksi tomat tergolong rendah, hal ini disebabkan karena penggunaan pupuk yang belum optimal serta media tanam yang belum tepat. Upaya untuk menanggulangi kendala tersebut adalah dengan perbaikan teknik budidaya. Salah satu teknik budidaya tanaman yang diharapkan dapat meningkatkan hasil dan kualitas tomat adalah hidroponik (Wasonowati, 2011). Menurut Lingga (2002) hidroponik merupakan cara budidaya tanaman tanpa menggunakan tanah sebagai media tanamnya. Budidaya tanaman dengan hidroponik memiliki banyak keuntungan seperti: 1) penggunaan lahan lebih efisien 2) penggunaan nutrisi lebih efisien, 3) tidak membutuhkan tenaga kerja yang banyak, 4) mudah perawatan, 5) produktivitas tanaman lebih tinggi dibandingkan dengan konvensional, 6) dan tidak dipengaruhi oleh iklim.

Serat aren hasil limbah industri tepung aren memiliki potensi sebagai bahan pengganti media pada sistem hidroponik substrat. Serat aren merupakan bahan organik yang mudah terdekomposisi karena memiliki sifat hidrofilik. Sifat tersebut dapat menyebabkan media substrat hidroponik cepat padat sehingga aerasi dalam media kurang. Menurut Arsyad et al. (2015) banyak cara pengolahan telah dilakukan untuk meningkatkan kompatibilitas serat alami, baik secara fisik maupun kimia yang bertujuan untuk memodifikasi permukaan serat.

Perlakuan kimia adalah salah satu metode untuk memperbaiki sifat serat alami seperti geometri permukaan, pembuangan kotoran, kekuatan serat, dan interaksi antara serat dan matriks. Salah satu perlakuan kimia yang telah dilakukan yakni dengan menggunakan boraks. Penelitian yang telah dilakukan oleh Handayani (2007) menunjukkan bahwa pengawetan dengan bahan kimia seperti boraks dapat memperbaiki sifat dan memperpanjang umur serat alami. Sifat boraks sebagai bahan pengawet berasal dari senyawa aktif asam borat. Senyawa ini dikenal sebagai zat antiseptik yang mampu membunuh bakteri pembusuk. Selanjutnya, serat aren yang telah diawetkan digunakan sebagai media tanam hidroponik. Penelitan ini menggunakan metode pengawetan serat aren ke dalam larutan boraks $\left(\mathrm{Na}_{2} \mathrm{~B}_{4} \mathrm{O}_{7}\right)$ yang bertujuan untuk menghambat proses dekomposisi sehingga dapat meningkatkan umur pakai serat aren sebagai media substrat untuk pertumbuhan dan hasil tomat. Tujuan peneltian ini adalah untuk mengetahui pengaruh boraks terhadap 
dekomposisi serat aren setelah digunakan untuk budidaya tomat.

\section{BAHAN DAN METODE}

Penelitian dilaksanakan di Rumah Kaca B dan Laboratorium Fisiologi Tumbuhan dan Bioteknologi Fakultas Pertanian, Universitas Sebelas Maret, Surakarta pada bulan Januari-Juli 2019. Alat yang digunakan dalam penelitian yaitu penggiling, drim, penggaris, timbangan analitik, alat tulis, polybag, benang kasur, label, rafia, ember, gelas ukur 2 liter, Electical Conductivity meter, jangka sorong, pH meter, termometer, botol spray, sarung tangan lateks, masker dan kamera. Bahan yang digunakan yaitu benih tomat varietas Servo dan Ken Dedes berumur 35 hari, serat aren, boraks, larutan nutrisi $A B$ mix, fungisida Gliocladium virens 1,64 x 1011 dan pestisida berbahan aktif Abamektin 18.4.

Metode penelitian yang digunakan yakni Rancangan Acak Lengkap (RAL) faktorial yang terdiri dari 2 faktor. Faktor pertama adalah waktu perendaman substrat serat aren pada pengawet boraks konsentrasi 10\%, yaitu 0 hari (kontrol, $\mathrm{H} 0$ ), 1 hari $(\mathrm{H} 1), 2$ hari $(\mathrm{H} 2), 3$ hari $(\mathrm{H} 3)$ dan 4 hari $(\mathrm{H} 4)$. Faktor kedua yakni macam varietas tomat yaitu varietas Servo dan varietas Ken Dedes. Setiap perlakuan diulang sebanyak 3 kali sehingga didapatkan 30 satuan percobaan.

Tahapan penelitian meliputi penggilingan, perendaman, penanaman, penyulaman, pemeliharaan, pemanenan dan pembongkaran media tanam. Variabel pengamatan meliputi persentase serat terdekomposisi, $\mathrm{pH}$ serat, kapasitas menahan air serat, tinggi tanaman, diameter batang, jumlah daun, bobot kering brangkasan, bobot buah per tanaman dan diameter buah. Teknik pengumpulan data dilakukan secara kuantitatif. Hasil data yang diperoleh dianalisis dengan menggunakan ANOVA dengan taraf $5 \%$ untuk membandingkan hasil perlakuan. Hasil analisis yang berpengaruh nyata (signifikan) kemudian dilanjutkan dengan uji Duncan Multiple Range Test (DMRT) pada taraf kepercayaan $95 \%$.

\section{HASIL DAN PEMBAHASAN \\ Persentase serat terdekomposisi}

Hasil penelitian menunjukkan bahwa waktu perendaman tidak memberikan pengaruh nyata terhadap persentase serat terdekomposisi (Tabel 1). Serat aren merupakan bahan organik yang berasal dari batang tanaman aren dan memiliki sifat mudah terdekomposisi. Muhsin (2011) menyatakan bahwa bahan organik bersifat dinamis, yaitu mudah terurai oleh aksi langsung sistem enzim jasad hidup yang ada di dalam tanah. Selama proses dekomposisi, bahan organik menjadi remah tidak berbau dan terjadi perubahan warna dari kuning kecoklatan menjadi coklat kehitaman seperti tanah. Hal ini karena pada proses dekomposisi terjadi proses mineralisasi sehingga nilai $\mathrm{C} / \mathrm{N}$ bahan organik turun mendekati $\mathrm{C} / \mathrm{N}$ tanah. Oleh karena itu bahan organik yang terdekomposisi warnanya menyerupai tanah (Murbandono, 1998; Mulyani et al., 1991). Hasil analisis ragam menunjukkan bahwa perlakuan perendaman boraks tidak memberikan pengaruh nyata terhadap penurunan persentase serat terdekomposisi. Hal ini dikarenakan perlakuan antar durasi perendaman memiliki tingkat serat terdekomposisi yang tidak jauh berbeda.

Tabel 1. Waktu perendaman serat aren dengan larutan boraks terhadap persentase serat terdekomposisi

\begin{tabular}{cc}
\hline Waktu perendaman (hari) & $\begin{array}{c}\text { Persentase serat } \\
\text { terdekomposisi (\%) }\end{array}$ \\
\hline Tanpa Perendaman & 64,78 \\
1 & 58,76 \\
2 & 67,15 \\
3 & 56,87 \\
4 & 66,85 \\
\hline
\end{tabular}

Pengawet boraks tidak mampu menghambat pertumbuhan dan perkembangan mikroorganisme didalam serat sehingga terjadi proses dekomposisi. Hal ini dikarenakan adanya faktor yang mempengaruhi seperti kapasitas menahan air. Semakin tinggi kapasitas serat aren dalam menahan air maka semakin banyak air yang terkandung di dalam serat. Selain itu, serat aren memiliki pori makro yang lebih besar sehingga nutrisi yang diberikan tidak dapat ditahan secara optimal. Pada dasar polybag tidak terdapat lubang drainase. Lubang drainase yang berada $1 \mathrm{~cm}$ dari dasar polybag mengakibatkan nutrisi menggenang. Faktor-faktor tersebut mengakibatkan kondisi di dalam media menjadi anaerob sehingga terjadi proses dekomposisi. Menurut Indarto (2010) dekomposisi anaerob merupakan proses dimana mikroorganisme tumbuh dan menggunakan energi dengan cara melakukan metabolisis bahan organik pada lingkungan anaerob dan menghasilkan metana. Proses tersebut dibagi menjadi tiga tahap, yaitu hidrolisis, pembentukan asam, dan pembentukan metana, masing-masing tahap tersebut menurut karakteristik kelompok mikroorganisme sendiri.

\section{pH serat}

Hasil penelitian menunjukkan bahwa waktu perendaman tidak memberikan pengaruh nyata terhadap $\mathrm{pH}$ serat (Tabel 2). Pengukuran $\mathrm{pH}$ yang telah dilakukan menunjukkan nilai yang positif karena semakin lama durasi perendaman akan meningkatkan $\mathrm{pH}$ serat aren menjadi basa. $\mathrm{pH}$ serat tanpa perendaman menunjukkan nilai terendah yakni 5.3, sedangkan nilai tertinggi terdapat pada serat dengan perendaman durasi 4 hari yakni 6.1.

Tabel 2. Waktu perendaman serat aren dengan larutan boraks terhadap $\mathrm{pH}$ serat aren

\begin{tabular}{cc}
\hline Waktu perendaman (hari) & pH serat \\
\hline Tanpa Perendaman & 5,3 \\
1 & 5,9 \\
2 & 6,0 \\
3 & 6,0 \\
4 & 6,1 \\
\hline
\end{tabular}

Meningkatnya nilai $\mathrm{pH}$ didukung oleh pernyataan Juhana et al. (2013) yang menyatakan bahwa asam borat (boraks) merupakan asam lemah dengan 
garam alkalinya yang bersifat basa. Pendapat yang sama dikemukakan oleh Richardson (1978) bahwa penambahan boraks dalam jumlah banyak dapat meningkatkan $\mathrm{pH}$, karena boraks bersifat basa.

\section{Water holding capacity}

Hasil penelitian menunjukkan bahwa waktu perendaman tidak memberikan pengaruh nyata terhadap water holding capacity (Tabel 3). Serat aren yang telah digiling memiliki ukuran yang lebih kecil dan memiliki pori mikro yang lebih banyak. Menurut Kusumaningsih (2017) bahan organik yang memiliki pori mikro (rongga sel) yang banyak, dapat menyebabkan larutan bahan pengawet mudah menyerap dan menghasilkan absorbsi yang tinggi. Bahan organik bersifat higroskopis sehingga bahan organik yang memiliki pori mikro yang banyak lebih mudah menyerap air. Bahan pengawet boraks berbentuk butiran halus dengan ukuran partikel yang kecil sehingga mudah masuk dan terserap ke dalam bahan organik yang diawetkan.

Tabel 3. Waktu perendaman serat aren dengan larutan boraks terhadap water holding capacity serat aren

\begin{tabular}{cc}
\hline Waktu perendaman (hari) & Water holding capacity \\
\hline Tanpa Perendaman & 2,26 \\
1 & 2,73 \\
2 & 2,97 \\
3 & 2,79 \\
4 & 2,61 \\
\hline
\end{tabular}

Hasil pengukuran yang telah dilakukan menunjukkan bahwa perendaman serat aren durasi 2 hari memiliki water holding capacity paling tinggi kemudian menurun pada perendaman durasi 3 dan 4 hari. Hal ini diduga karena pada waktu perendaman hari ke-3 dan 4 terlalu lama sehingga menyebabkan partikel pada larutan boraks mengisi sebagian besar pori mikro pada serat aren dan menyebabkan air tidak dapat diserap lebih banyak. Perendaman serat aren dengan durasi 2 hari diduga sebagai durasi perendaman yang dapat meningkatkan water holding capacity.

\section{Tinggi tanaman}

Analisis data yang digunakan yakni tinggi tanaman pada minggu ke-4. Pertimbangan ini dilakukan karena pada minggu ke-5 bunga sudah mulai muncul sehingga minggu ke-4 menjadi batas fase vegetatif maksimum.

Tabel 4. Waktu perendaman serat aren dengan larutan boraks terhadap tinggi tanaman

\begin{tabular}{cc}
\hline Waktu perendaman (hari) & Tinggi tanaman (cm) \\
\hline Tanpa Perendaman & 47,52 \\
1 & 39,60 \\
2 & 42,78 \\
3 & 44,20 \\
4 & 47,13 \\
\hline
\end{tabular}

Hasil analisis menunjukkan bahwa perlakuan perendaman dengan larutan boraks tidak memberikan pengaruh nyata terhadap tinggi tanaman dua varietas tomat (Tabel 4). Hal ini diduga karena waktu perendaman serat aren kurang optimal untuk meningkatkan tinggi tanaman. Perendaman serat aren dengan larutan boraks tidak berpengaruh nyata terhadap tinggi tanaman pada dua jenis varietas tomat.

Tabel 5. Tinggi tanaman pada 2 varietas tomat

\begin{tabular}{cc}
\hline Varietas tomat & Tinggi tanaman $(\mathrm{cm})$ \\
\hline Servo & 45,31 \\
Ken Dedes & 43,18 \\
\hline
\end{tabular}

Hasil analisis menunjukkan bahwa perlakuan varietas tomat tidak memberikan pengaruh nyata terhadap tinggi tanaman (Tabel 5). Menurut Sitompul dan Guritno (1995) tinggi tanaman pada umur dibawah 95 HST tidak berbeda nyata karena pada saat umur pertumbuhan tersebut, mikroorganisme masih belum melakukan aktivitasnya secara penuh dalam menyediakan hara tersedia bagi tanaman, akan tetapi mikroorganisme tersebut menyerap unsur hara yang telah tersedia pada nutrisi $A B$ mix sebagai sumber energi. Sehingga terjadi kompetisi antara akar tanaman dan mikroorganisme dalam menyerap hara dan mengakibatkan unsur hara yang terdapat pada nutrisi $A B$ mix belum dapat dimanfaatkan secara optimal oleh tanaman. Akar menyerap hara untuk pertumbuhan tanaman itu sendiri, sedangkan mikroorganisme menyerap hara untuk mendapatkan energi dan kemudian digunakan untuk menguraikan serat aren.

\section{Diameter batang}

Perlakuan waktu perendaman serat aren dengan larutan boraks memberikan pengaruh nyata terhadap diameter batang (Tabel 6).

Tabel 6. Waktu perendaman serat aren dengan larutan boraks terhadap diameter batang tanaman

\begin{tabular}{ccc}
\hline Waktu perendaman (hari) & Diameter batang $(\mathrm{mm})$ \\
\hline Tanpa Perendaman & $1,60 \mathrm{ab}$ \\
1 & $1,18 \mathrm{a}$ \\
2 & 1.77 & $\mathrm{~b}$ \\
3 & $1.60 \mathrm{ab}$ \\
4 & 1.13 & $\mathrm{a}$ \\
\hline
\end{tabular}

Keterangan : Angka yang diikuti huruf yang sama tidak berbeda nyata pada DMRT taraf 5\%

Batang memiliki fungsi untuk menyalurkan air dan nutrisi yang diserap akar tanaman menuju daun untuk proses fotosintesis dan menyalurkannya ke seluruh organ tanaman. Pertumbuhan diameter batang yang baik akan membantu akar untuk menyuplai air untuk pertumbuhan tanaman pada fase vegetatif dan fase generatif. Selain itu, pertumbuhan diameter batang yang semakin besar akan membantu menopang tanaman agar tidak mudah patah (Nasrulloh et al., 2016).

Hasil pengukuran diameter batang yang telah dilakukan menunjukkan bahwa perendaman serat aren dengan larutan boraks memberikan pengaruh nyata terhadap diameter batang dua varietas tomat (Tabel 7). Diameter batang tertinggi terdapat pada perendaman serat aren selama 2 hari. Sedangkan 
diameter batang terendah terdapat pada perendaman serat aren selama 4 hari. Hal ini disebabkan karena pada perendaman serat aren selama 2 hari memiliki kapasitas menahan air tertinggi.

Tabel 7. Diameter batang tanaman pada 2 varietas tomat

\begin{tabular}{cc}
\hline Varietas tomat & Diameter batang $(\mathrm{mm})$ \\
\hline Servo & $1,55 \mathrm{a}$ \\
Ken Dedes & $1,36 \mathrm{a}$ \\
\hline
\end{tabular}

Keterangan : Angka yang diikuti huruf yang sama tidak berbeda nyata pada DMRT taraf 5\%

Tomat varietas Servo memiliki diameter batang yang lebih besar dari pada tomat varietas Ken Dedes. Tanaman dalam pertumbuhannya membutuhkan air dan unsur hara untuk berfotosintesis dan menghasilkan fotosintat. Pernyataan ini didukung oleh Riskiyah (2014) bahwa pertumbuhan tanaman dipengaruhi oleh beberapa faktor, salah satunya yakni terpenuhinya kebutuhan air bagi tanaman, karena bahan terbesar penyusun jaringan tanaman adalah air. Air menjadi bahan yang sangat penting bagi tanaman untuk melakukan fotosintesis dan menghasilkan fotosintat yang kemudian disalurkan ke seluruh bagian tanaman. Fujita et al. (2003) menyatakan bahwa diameter batang dan buah tanaman berfluktuasi setiap hari bertepatan dengan perubahan status air di dalam tanaman.

\section{Jumlah daun}

Perlakuan perendaman serat aren dengan larutan boraks tidak memberikan pengaruh nyata terhadap jumlah daun majemuk pada dua jenis varietas tomat (Tabel 8).

Tabel 8. Waktu perendaman serat aren dengan larutan boraks terhadap jumlah daun tanaman

\begin{tabular}{cc}
\hline $\begin{array}{c}\text { Waktu perendaman } \\
\text { (hari) }\end{array}$ & Jumlah daun (helai) \\
\hline Tanpa Perendaman & 10,50 \\
1 & 9,5 \\
2 & 11,33 \\
3 & 13,83 \\
4 & 10,67 \\
\hline
\end{tabular}

Perendaman serat aren dengan larutan boraks tidak memberikan pengaruh secara nyata terhadap jumlah daun majemuk dua varietas tomat. Hal ini disebabkan oleh kurangnya unsur hara dan air yang diserap oleh tanaman. Hal ini diduga karena adanya kompetisi antara akar tanaman dan mikroorganisme dalam menyerap hara sehingga nutrisi $A B$ mix tidak dapat diserap secara optimal oleh akar tanaman. Sependapat dengan Fitriani dan Haryanti (2016) bahwa organ daun berkembang dari sel-sel meristematik yang kemudian membentuk tunas yang jumlahnya dipengaruhi oleh kandungan unsur hara dan air yang diserap. Semakin banyak penyerapan unsur hara, maka pembentukan tunas daun menjadi lebih banyak.

Hasil penelitian menunjukkan bahwa varietas tomat tidak memberikan pengaruh nyata terhadap jumlah daun (Tabel 10). Pada pembahasan variabel serat, dikatakan bahwa serat aren memiliki pori makro yang lebih besar sehingga nutrisi yang diberikan tidak dapat ditahan secara optimal dan menggenang pada dasar polybag. Pengukuran jumlah daun dilakukan pada saat tanaman berumur maksimal 4 minggu setelah tanam. Diduga pada saat itu, akar tanaman belum mencapai dasar polybag sehingga penyerapan nutrisi kurang optimal.

Tabel 9. Jumlah daun tanaman pada 2 varietas tomat

\begin{tabular}{cc}
\hline Varietas tomat & Jumlah daun (helai) \\
\hline Servo & 11,07 \\
Ken Dedes & 11,27 \\
\hline
\end{tabular}

Dugaan lain yakni apabila akar tanaman sudah mencapai dasar polybag, maka pertumbuhan tomat juga terhambat karena banyaknya air yang menggenang. Hal ini dikarenakan kurangnya kadar oksigen pada akar sehingga akar kurang optimal menyerap nutrisi bahkan dapat menyebabkan jadi busuk. Lutfyrachman et al. (2013) menyatakan bahwa tanaman tomat membutuhkan air yang banyak, namun tidak dalam jumlah yang berlebihan. Akar tanaman tomat tidak mampu berfungsi dengan baik pada keadaan yang tergenang, hal ini dapat menyebabkan pertumbuhan tanaman terhambat.

\section{Bobot kering brangkasan}

Hasil penelitian menunjukkan bahwa waktu perendaman tidak memberikan pengaruh nyata terhadap bobot kering brangkasan (Tabel 10). Sitompul dan Guritno (1995) menyatakan bahwa bahan tanaman yang kering merupakan manivestasi dari semua proses dan peristiwa yang terjadi dalam pertumbuhan tanaman. Alasan tersebut menjadikan bobot kering brangkasan dapat digunakan sebagai ukuran global pertumbuhan tanaman. Berdasarkan pengamatan yang telah dilakukan dapat diketahui bahwa perendaman serat aren dengan larutan boraks tidak memberikan pengaruh nyata terhadap bobot kering brangkasan dua varietas tomat. Hasil perlakuan perendaman menunjukkan bahwa bobot kering brangkasan dua varietas tomat tidak berbeda secara signifikan.

Tabel 10. Waktu perendaman serat aren dengan larutan boraks terhadap bobot kering brangkasan

\begin{tabular}{cc}
\hline $\begin{array}{c}\text { Waktu perendaman } \\
\text { (hari) }\end{array}$ & $\begin{array}{c}\text { Bobot kering brangkasan } \\
(\mathrm{g})\end{array}$ \\
\hline Tanpa Perendaman & 46,67 \\
1 & 23,28 \\
2 & 34,86 \\
3 & 41,24 \\
4 & 48,72 \\
\hline
\end{tabular}

Hasil penelitian menunjukkan bahwa waktu perendaman tidak memberikan pengaruh nyata terhadap bobot kering brangkasan (Tabel 11). Bobot kering brangkasan menurut Parera (1997) dipengaruhi oleh penyerapan air yang kemudian mendorong pemanjangan sel dan pembesaran sel. Apabila pertumbuhan tinggi tanaman dan jumlah daun mengalami peningkatan, maka bobot kering brangkasan juga meningkat. Hal ini disebabkan karena terjadinya proses pembelahan dan 
perbanyakan sel terutama pada bagian ujung tanaman atau jaringan meristem.

Tabel 11. Bobot kering brangkasan pada 2 varietas tomat

\begin{tabular}{cc} 
Varietas tomat & $\begin{array}{c}\text { Bobot kering } \\
\text { brangkasan }(\mathrm{g})\end{array}$ \\
\hline Servo & 37,98 \\
Ken Dedes & 39,93 \\
\hline
\end{tabular}

Bobot kering brangkasan menurut Pujisiswanto dan Pangaribuan (2008) menunjukkan hasil dari translokasi hasil fotosintesis (fotosintat) ke seluruh bagian tanaman, sehingga dapat dikatakan laju pertumbuhan tanaman sangat ditentukan oleh luas daun tanaman yang mampu mengintersepsi sinar matahari langsung secara maksimum dan laju fotosintesis tanaman.

\section{Bobot buah per tanaman}

Buah tomat berkembang dari ovarium setelah pembuahan ovula. Dinding ovarium akan berubah menjadi pericarp yang merupakan bagian terbesar dari buah (Monforte et al., 2014). Menurut Gillaspy et al. (1993) setelah pembuahan ovula berhasil, pericarp, columella dan jaringan plasenta akan berkembang melalui pembelahan sel yang meningkat selama 5-10 hari setelah penyerbukan. Proses ini diikuti oleh pembesaran sel yang meningkatkan massa buah. Selanjutnya proses pematangan buah memiliki tahap awal ditandai dengan peningkatan pembelahan sel diikuti oleh ekspansi sel. Setelah ukuran buah maksimal, proses pematangan terjadi yang ditandai oleh perubahan biokimia pada buah yang matang (Giovannoni, 2004; Gapper et al., 2013).

Tabel 12. Waktu perendaman serat aren dengan larutan boraks terhadap bobot buah per tanaman

\begin{tabular}{cc}
\hline $\begin{array}{c}\text { Waktu perendaman } \\
\text { (hari) }\end{array}$ & $\begin{array}{c}\text { Bobot buah per } \\
\text { tanaman }(\mathrm{g})\end{array}$ \\
\hline Tanpa Perendaman & 63,86 ab \\
1 & $85,31 \quad \mathrm{~b}$ \\
2 & $29,11 \mathrm{a}$ \\
3 & $55,33 \mathrm{ab}$ \\
4 & $82,89 \quad \mathrm{~b}$ \\
\hline
\end{tabular}

Keterangan : Angka yang diikuti huruf yang sama tidak berbeda nyata pada DMRT taraf $5 \%$

Bobot buah per tanaman dihitung dari bobot total buah 3 ulangan tiap perlakuan. Bobot buah per tanaman merupakan indikator untuk menentukan hasil atau produksi buah yang dapat dihasilkan tanaman di tiap perlakuan. Berdasarkan hasil analisis menunjukkan bahwa perendaman serat aren dengan larutan boraks tidak memberikan pengaruh nyata terhadap bobot buah per tanaman dua varietas tomat (Tabel 12). Banyak faktor yang dapat mempengaruhi bobot buah tanaman diantaranya adalah faktor iklim seperti suhu, kelembaban, cahaya dan angin. Kemudian faktor lingkungan yang terbagi menjadi dua yakni lingkungan biotik dan lingkungan abiotik. Lingkungan biotik meliputi organisme pengganggu tanaman, pollinator, kompetisi antar tanaman dan kompetisi dengan mikroorganisme di dalam media tanam. Sedangkan lingkungan abiotik yakni media serat aren. Selain itu ada faktor dari tanaman itu sendiri seperti jumlah bunga, jumlah bunga berhasil dan genetik tanaman. Faktor lain yang dapat mempengaruhi yakni kecukupan air dan nutrisi pada media tanam. Menurut Nasrulloh (2016) bahwa kecukupan air pada saat pembuahan mempengaruhi jumlah dan bobot buah yang dihasilkan oleh tanaman karena air sangat penting untuk berlangsungnya proses fotosintesis sehingga berpengaruh terhadap banyaknya fotosintat yang dihasilkan. Fotosintat tersebut kemudian disalurkan ke seluruh organ tanaman termasuk untuk pertumbuhan buah. Proses fotosintesis yang berjalan optimal tanpa gangguan akan berpengaruh terhadap jumlah dan bobot buah tomat.

Tabel 13. Bobot buah per tanaman pada 2 varietas tomat

\begin{tabular}{cc}
\hline Varietas tomat & $\begin{array}{c}\text { Bobot buah per } \\
\text { tanaman }(\mathrm{g})\end{array}$ \\
\hline Servo & 61,90 \\
Ken Dedes & 64,69 \\
\hline
\end{tabular}

Pada macam varietas tomat menunjukkan bahwa bobot total buah per tanaman tidak berbeda secara nyata pada dua varietas tomat (Tabel 13). Faktor yang diduga mempengaruhi bobot buah per tanaman yakni keberhasilan bunga menjadi buah. Keberhasilan bunga tanaman tomat sangat bergantung pada suhu di dalam greenhouse. Menurut Peet dan Bartholemew (1986) suhu optimal untuk pertumbuhan dan pembungaan tomat adalah $21-24^{\circ} \mathrm{C}$ pada siang hari dan $18-22^{\circ} \mathrm{C}$ pada malam hari. Kuo dan Tsai (1984) menyatakan bahwa suhu tinggi di daerah tropis menyebabkan rendahnya perkembangan polen, berkurangnya proses penyerbukan, hancurnya sel embrio pada putik dan rendahnya kandungan auksin dan giberelin yang dapat menghambat pembentukan buah. Harjadi (1989) menambahkan bahwa cahaya yang terlalu terik dapat meningkatkan transpirasi dan gugur bunga serta buah.

\section{Diameter buah per tanaman}

Diameter buah merupakan salah satu parameter produksi tanaman. Menurut Olaniyi et al. (2010) dan Regassa et al. (2012) beberapa komponen produksi tomat meliputi jumlah bunga, jumlah bunga per tandan, jumlah buah, bobot buah, panjang buah, dan diameter buah. Diameter buah mulai berkembang setelah proses penyerbukan hingga mencapai ukuran maksimum. Pernyataan ini didukung oleh Cong et al. (2002) dan Liu et al. (2003) bahwa peningkatan ukuran buah terjadi setelah bunga mekar (anthesis) dan dominan pada jaringan plasenta buah tomat yang sedang berkembang.

Hasil pengukuran diameter buah menunjukkan bahwa waktu perendaman serat aren dengan larutan boraks tidak memberikan pengaruh nyata terhadap diameter buah dua varietas tomat (Tabel 14). Hal ini diduga karena penyerapan nutrisi oleh akar tanaman kurang optimal. Akar tanaman tumbuh hingga dasar polybag yang kondisi medianya tergenang oleh 
larutan nutrisi kemudian menyebabkan akar menjadi busuk sehingga aerasi pada akar tanaman kurang. Tanaman tomat membutuhkan air untuk pertumbuhan dan perkembangannya. Namun, kandungan air yang berlebihan dapat menurunkan pertumbuhan dan produksi tanaman tomat. Menurut Riskiyah (2014) apabila suplai air pada saat pertumbuhan vegetatif tidak optimal, maka pertumbuhan dan perkembangan sel terhambat, daun menjadi kecil sehingga hanya sedikit fotosintat yang dapat ditranslokasikan ke buah, akibatnya ukuran buah menjadi lebih kecil. Apabila defisit air terjadi setelah perluasan daun terutama selama pengisian buah atau biji maka akan terjadi persaingan antara daun dan biji dalam memanfaatkan fotosintat sehingga buah yang terbentuk relatif lebih sedikit dan menyebabkan ukuran buah kecil sehingga mempengaruhi bobot serta kualitas buah yang dihasilkan.

Tabel 14. Waktu perendaman serat aren dengan larutan boraks terhadap diameter buah per tanaman

\begin{tabular}{cc}
\hline $\begin{array}{c}\text { Waktu perendaman } \\
\text { (hari) }\end{array}$ & $\begin{array}{c}\text { Diameter buah per } \\
\text { tanaman }(\mathrm{g})\end{array}$ \\
\hline Tanpa Perendaman & 19,42 \\
1 & 19,40 \\
2 & 19,35 \\
3 & 24,24 \\
4 & 27,24 \\
\hline
\end{tabular}

Hasil analisis menunjukkan bahwa diameter buah per tanaman pada dua varietas tomat tidak berbeda secara signifikan (Tabel 15). Faktor lain yang mempengaruhi besar kecilnya diameter buah yakni waktu muncul bunga. Susanto et al. (2010) menyatakan bahwa buah yang dihasilkan oleh bunga primer lebih besar dari bunga sekunder, buah dari bunga sekunder lebih besar dari bunga tersier. Selain itu faktor lingkungan, faktor genetik dan respon tanaman terhadap lingkungan yang berbeda pada setiap tanaman juga dapat mempengaruhi ukuran diameter buah.

Tabel 15. Diameter buah per tanaman pada 2 varietas tomat

\begin{tabular}{cc}
\hline Varietas tomat & $\begin{array}{c}\text { Diameter buah per } \\
\text { tanaman }(\mathrm{g})\end{array}$ \\
\hline Servo & 21,24 \\
Ken Dedes & 22,61 \\
\hline
\end{tabular}

\section{KESIMPULAN}

Larutan boraks tidak dapat digunakan sebagai bahan pengawet substrat serat aren. Perlakuan waktu perendaman berpengaruh nyata terhadap diameter batang dan bobot buah per tanaman. Perlakuan varietas tomat berpengaruh nyata terhadap diameter batang. Perlu dilakukan modifikasi serat aren sebagai media untuk hidroponik substrat untuk mengatasi kelemahan substrat serat aren.

\section{DAFTAR PUSTAKA}

Arsyad, M., Wardana, I. N. G., Pratikto, \& Irawan, Y. S. (2015). The morphology of coconut fiber surface under chemical treatment. Department of
Mechanical Engineering, Brawijaya University, Malang, Indonesia.

Cong, B., Liu, J. P., \& Tanksley, S. D. (2002). Natural alleles at a tomato fruit size quantitative trait locus differ by heterochronic regulatory mutations. Proceedings of the National Academy of Sciences, USA 99,13606-13611.

Fitriani, H. P., \& Haryanti, S. (2016). Pengaruh penggunaan pupuk nanosilika terhadap pertumbuhan tanaman tomat (Solanum lycopersicum) var. Bulat. Buletin anatomi dan fisiologi. 24(1).

Fujita, K., Okada, M., Lei, K., Ito, J., Ohkura, K., Adu-Gyam, J. J., \& Mohapatra, P. K. (2003). Effect of $P$-deciency on photoassimilate partitioning and rhythmic changes in fruit and stem diameter of tomato (Lycopersicon esculentum) during fruit growth. Journal of Experimental Botany 54(392):2519-2528.

Gapper, N. E., McQuinn, R. P., \& Giovannoni, J. J. (2013). Molecular and genetic regulation of fruit ripening. Plant Molecular Biology 82, 575-591.

Gillaspy, G., Bendavid, H., \& Gruissem, W. (1993). Fruits a developmental perspective. Plant Cell 5:1439-1451.

Giovannoni, J. J. (2004). Genetic regulation of fruit development and ripening. Plant Cell 16:S170-S180.

Handayani, S. (2007). Pengujian Sifat Mekanik Bambu (Metode Pengawetan dengan Boraks). Jurnal Teknik Sipil \& Perencanaan 9(1): 43 - 53

Harjadi, S. S. (1989). Dasar-Dasar Hortikultura. Jurusan Budidaya Pertanian. Institut Pertanian Bogor, Bogor.

Indarto, K. E. (2010). Produksi biogas limbah cair industri tapioka melalui peningkatan suhu dan penambahan urea pada perombakan anaerob. Skripsi. Fakultas Matematika dan IImu Pengetahuan Alam. Universitas Sebelas Maret, Surakarta.

Juhana, H. A., Intarniati, N. R., \& Intarniati, N. R. (2013). Pengaruh Pemberian Boraks Dengan Dosis Bertingkat Terhadap Perubahan Makroskopis dan Mikrokskopis Ginjal Tikus Wistar Selama 4 Minggu Dilanjutkan 2 Minggu Tanpa Paparan Boraks (Doctoral dissertation). Fakultas Kedokteran Universitas Diponegoro, Semarang.

Kuo, C. G., \& Tsai, C. T. (1984). Alternation by high temperature of high temperature of auxin and giberellin concentration in the floral buds, flower and young fruit of tomato. Hort Science. 9(6):870-874.

Kusumaningsih, K. R. (2017). Sifat Penyerapan Bahan Pengawet Pada Beberapa Jenis Kayu Bangunan. Fakultas Kehutanan Institut Pertanian Stiper Yogyakarta. Jurnal Wana Tropika.

Liu, J. P., Cong, B., \& Tanksley, S. D. (2003). Generation and analysis of an artificial gene dosage series in tomato to study the mechanisms 
by which the cloned quantitative trait locus fw2.2 controls fruit size. Plant Physiology 132: 292-299.

Lutfyrachman, H., \& Anas, D. S. (2013). Optimasi dosis pupuk anorganik dan pupuk kendang ayam pada budidaya tomat hibrida (Lycopersicon esculentum Mill). Bul. Agrohorti 1(1): 119-126.

Monforte, A. J., Diaz, A., Caño-Delgado, A., \& Knaap, E. V. D. (2014). The genetic basis of fruit morphology in horticultural crops: lessons from tomato and melon. Journal of Experimental Botany 65(16): 4625-4637.

Muhsin, A. (2011). Pemanfaatan Limbah Hasil Pengolahan Pabrik Tebu Blotong Menjadi Pupuk Organik. Industrial Engineering Conference.

Mulyani, S., Kartasapoetra, \& Sastroatmodjo. (1991). Mikrobiologi Tanah. Rineka Cipta, Jakarta. 447 p

Murbandono. (1998). Membuat Kompos. Penebar Swadaya, Jakarta. 44 p.

Nasrulloh, A. T., Mutiarawati, W., \& Sutari. (2016). Pengaruh penambahan arang sekam dan jumlah cabang produksi terhadap pertumbuhan tanaman, hasil dan kualitas buah tomat kultivar doufu hasil sambung batang pada Inceptisol Jatinangor. Department of Crop Science, Padjadjaran University. Jurnal Kultivasi. 15(1).

Olaniyi, J. O., Akanbi, W. B., Adejumo, T. A., \& Akande, O. G. (2010). Growth, fruit yield and nutritional quality of tomato varieties. African Journal of Food Science 4(6): 398-402.
Parera. (1997). Pengaruh Tingkat Konsentrasi Pertumbuhan Perbanyakan Tanaman Anggrek Dendrobium melalui Teknik Kultur Jaringan. Hal: 57-64.

Peet, M. M., \& Bartholemew, M. (1986). Effect of night temperature on pollen characteristic, growth, and fruit set in tomato. J. Amer. Soc. Hort. Sci. 12(3): 514-519.

Pujisiswanto, H., \& Pangaribuan, D. (2008). Pengaruh Dosis Kompos Pupuk Kandang Sapi Terhadap Pertumbuhan dan Produksi Buah Tomat. Prosiding Seminar Nasional Sains dan Teknologi-II 2008. Universitas Lampung, 17-18 November 2008. ISBN : 978-979-1165-74-7.

Richardson, B. A. (1978). Wood Preservation. The Construction Press Ltd. Lancaster. p. 37.

Riskiyah, J. (2014). Uji volume air pada berbagai varietas tanaman tomat (Lycopersicum esculentum Mill). Jurnal Unri 1(1) : 1-9.

Regassa, M. D., Mohammed, A., \& Bantte, K. (2012). Evaluation of tomato (Lycopersicon esculentum Mill.) genotypes for yield and yield components. African of Plant Science and Biotechnology 6(1): 45-49.

Sitompul, S. M., \& Guritno, B. (1995). Analisis Pertumbuhan Tanaman. Gadjah Mada University Press, Yogyakarta. 